\title{
Promoting Thai EFL Learners' Ability to Self-correct Errors in Written English Sentences through Games
}

\author{
Kanyakorn Sermsook ${ }^{1}$, Jiraporn Liamnimitr ${ }^{1} \&$ Vikrom Chantarangkul $^{1}$ \\ ${ }^{1}$ Department of Foreign Languages, Faculty of Science and Technology, Rajamangala University of Technology \\ Srivijaya, Nakhon Si Thammarat, Thailand \\ Correspondence: Kanyakorn Sermsook, Department of Foreign Languages, Faculty of Science and Technology, \\ Rajamangala University of Technology Srivijaya, Nakhon Si Thammarat, 80110, Thailand.
}

Received: April 21, 2020

doi: 10.5539/elt.v13n6p118
Accepted: May 25, 2020

Online Published: May 29, 2020

URL: https://doi.org/10.5539/elt.v13n6p118

\begin{abstract}
Games have been widely accepted as an effective tool for language learning. They help learners achieve better learning outcome and create a learning atmosphere which contribute to learners' learning. The present study, hence, employed games to help EFL learners write better in English. In the present study, games were used to encourage Thai EFL learners to self-correct errors found in their English sentences. After five weeks of learning with games, the learners' ability to self-correct errors was observed. Their posttest average score $(\bar{x}=18.65$, S.D. $=6.05)$ was higher than the pretest one $(\bar{x}=13.58$, S.D. $=6.45)$. The results from the paired samples t-test indicated a statistically significant difference at the 0.01 level which meant that games helped promote this group of learners to self-correct errors in written English sentences. Furthermore, the learners reported that they enjoyed English writing classes with games because they motivated them to learn English in a relaxing class. The learners' good interaction and collaboration were also observed during the games. The findings from this study imply that games should be incorporated in language classes for learners' positive learning outcome.
\end{abstract}

Keywords: EFL learners, English sentences, English writing, errors, games, self-correct

\section{Introduction}

\subsection{Background of the Study}

Games have been accepted as a valuable tool for language learning since they can enhance learners' language uses. They can also create an enjoyable learning atmosphere and friendly interaction among learners (Ashok, Revathi, \& Saminathan, 2013; Khunmohammad, Gorjian, \& Eskandari, 2014; Klimova, 2015; Martin, 2016). A great number of scholars, therefore, used games to improve language learners' learning performance. And there is no exception for using games to develop performance of learners who study English, a universal language (Crystal, 1997; Jenkins, 2003).

Games have been used in English classes to improve learners' use of the four skills of English: listening, speaking, reading and writing. In the study of Andyani (2012), it is reported that learners' listening ability was improved after learning with games for a period of time. For English reading, Huy (2016) stated that after learning with games, her participants' reading ability was developed. The effectiveness of games on the improvement of English writing can be seen in the study of Wulandari (2016) where she concluded that EFL learners' writing ability could be developed through games after her review of related literature.

Games were also used to improve learners' communication skills as can be seen in the studies of Chantarangkul \& Campos (2018) and Tanasavate (2018). The findings from these two studies reported the effectiveness of games on EFL learners' English communication. Moreover, these studies asserted that learners showed their satisfaction with using games in the classes. In addition, games were employed to help learners learn and remember English vocabulary. In the studies of Khumrod, Yiamkhantithaworn, \& Meejiang (2016) and Thongkul \& Sermsook (2017), EFL learners' vocabulary knowledge was improved after game-based learning for a certain period of time, and learners mentioned that games encouraged them to learn in a stress-free learning atmosphere. Additionally, learners' English grammar knowledge can be enhanced through games. In the study of Ashok et al. (2013), EFL learners' English grammar knowledge was significantly noticed after learning with games. 


\subsection{Statement of the Problem}

The studies mentioned above reveal that games not only improve learners' language learning performance in the four skills of English, but they also change EFL learners to have better attitudes toward English learning. Having learned the effectiveness of games on EFL learners' performance, the researchers believed that this technigue would be able to help improve Thai EFL learners' English writing performance. As throughout the time of being English writing teachers, the researchers found that Thai EFL learners faced difficulties when they had to write English sentences. Their written English sentences contained various types of errors, such as misspelling, subject-verb disagreement, wrong use of words and tenses, etc. Some of these incorrect sentences may lead to failure in cross-cultural communication. For instance, "I like look movies." which was a sentence written by one of the students in an English writing class was not correct due to his wrong word use. According to native speakers, this sentence could not fully convey its real meaning which the writer would like to mean that he likes to watch movies.

In addition, based on the experiences as English writing teachers, it can be said that in an English writing class, learners were stressed and bored, so the researchers would like to make the classroom entertaining and motivating by using games. Through this mean, the researchers hope that learners can be encouraged to learn and have positive attitudes toward learning to write in English.

The reseachers, therefore, would like to use games to promote Thai EFL learners' ability to self-correct errors in their written English sentences and to make them have positive attitudes toward English writing. Hopefully, the results from this study would be beneficial to teachers who search for an approach to improve learners' English writing ability and learners who want to develop their writing skills. More importantly, the researchers hope that this technique would help develop learners' self-detection and self-correction of errors they may encounter.

\section{Literature Review}

\subsection{Instructional Games and Their Characteristics}

Games for language learning have been defined by a considerable number of scholars. Bush (2015), for instance, defines games for language learning as the activities which enhance both interaction and competition among learners. They must be designed in order to let learners use the language. Another scholar, El Shamy (2001, as cited in Ibrahim, 2017) states that games are competitive events governed by rules where learners participate to accomplish the learning targets. Klimova (2015) mentions that games are fun and meaningful activities that need to be controlled by a precise number of regulations in order to make them the most effective for language learning. Moreover, they let learners learn the language creatively in a stress-free atmosphere which will result in their better learning outcome.

Koksal, Cekic, \& Beyhan (2014) describe that games are the techniques used in a language class to arouse learners' learning performance and boost up their confidence in using the language. Games, furthermore, create good interaction and collaboration among learners. Kim (2000) and Chen (2005) propose that games are useful in a language classroom because they are motivating and challenging activities that help reduce learners' anxiety and attract them to learn in a meaningful learning atmosphere. They both further state that games can be applied to any skills of languages: listening, speaking, reading and writing. Chen (2005), moreover, posits that games enhance interaction among learners and let them use the language creatively and promptly.

To make games the most beneficial and effective for language learning, they should possess some specific characteristics. Ibrahim (2017) mentions that games for language learning need to be rule-governed and easy to play. They must be in the form of competition which is designed for the target group of learners. Ampaipan (1999, as cited in Chirandon, Laohawiriyanon, \& Rakthong (2010)) proposes six factors for games selection which are 1. Numbers of learners 2. Place for game playing 3. Learners' age 4. Learners' language proficiency 5. Lesson and period of time and 6. Language difficulty.

Another scholar, Constantinescu (2012) provides the guidelines for game designing. He states that games should be purposive, enthusiastic and motivating. They should let learners fully use the language and should be related to lesson content. According to Constantinescu (2012), games should be also easy to understand and able to play in a proper period of time in order to interest learners. Furthermore, they should be suitable for learners' age and language ability. Likewise, Limantoro (2018) concluded that games must be appropriate for learners' age, language level and their background knowledge.

To conclude, games are fun and purposive activities employed in class to assist learners to learn and use the language in a relaxing atmosphere in order to achieve the lesson target. Although games can be useful for language learning, they need to be designed based on some relating factors, such as learners' age, language 
proficiency and numbers of learners. Other factors that cannot be overlooked are lesson content and time for game playing.

\subsection{Games for Language Error Correction}

Some scholars have designed and come up with useful games in order to develop learners' performance in language use. For example, Lackman (2010) mentions that games can allow learners to know and self-correct their language errors. He posits that game designers should take into account some relating factors, such as errors frequently made by learners in order to make those games the most effective. In addition, Case (2019) states that games can improve learners' language use and turn a boring classroom into a more interesting one; therefore, he invented some games. The following are some useful games created for language error correction.

1) Common error matching where learners have to match wrong sentences with the correct error type

2) Error correction race, a game that lets learners find errors that match error types and numbers of errors indicated by their teachers

3) Error correction pairwork where two learners work together to decide which one from the two given sentences is correct

4) Error correction mastermind which needs learners to find and correct all of the errors in a piece of writing

5) Error correction strip race that needs learners to work in teams to correct errors

6) Grammar auctions and variations which is the game where learners bid as many correct sentences as they can in order to be a winner.

In summary, games for language error correction are various. Some games let learners work individually. Others need two learners to work together, and learners have to work in teams in some games. Consequently, language teachers should consider which game is the most suitable and effective for their learners' language improvement. As the present study focused on promoting EFL learners' error self-correction, some techniques used in the above-mentioned games were applied.

\subsection{Previous Studies on Using Games to Enhance EFL Learners' English Language Learning}

Games were employed to improve EFL learners' ability of English use as can be viewed in a considerable number of studies. Ashok et al. (2013), for instance, stated that games contributed to learners' English improvement after comparing the performance of two groups of learners. The first group learned English through games; whereas, the other learned without games. After a 6-week experiment, they found that English proficiency of the learners learning with games outperformed the other group. Similarly, Bush (2015) compared the English learning outcome of two groups of learners, 17 each. The experimental group studied the present perfect tense with games. The controlled one studied the same topic without games. Though slight differences were observed in the mean scores of the two groups, the group in game-incorporated classroom agreed that games motivated them to learn. Likewise, in the study of Cam \& Thu Tran (2017), games were used to develop 25 English major learners' grammar knowledge. After six weeks, the learners' knowledge was improved, and they were satisfied with using games in the classroom. They mentioned that games made the English class motivating and relaxing. Moreover, they were able to use English for their communication.

The usefulness of games on English grammar can be seen from the findings in another type of study conducted by Koksal et al. (2014). In this study, questionnaires were used to survey learners' attitudes toward learning English grammar with games. Based on the analysis, it can be said that learners found the importance and benefits of games on their English learning. They were more confident to use grammar in their English sentences, and games made them happy with their learning. In another study by Sermsook (2018), an error self-correcting game was designed and used to encourage 30 English major learners to self-correct grammatical errors in English sentences. The results from the observation showed that the class was relaxing, and the learners enjoyed the game. They said that the game helped them correct the errors and motivated them to learn. The learners' good interaction was seen while they were playing the game.

Games can also be used to promote learners' other English skills. In the study of Andyani (2012), for example, games were employed to improve the English listening skill of 36 EFL learners in a high school in Indonesia. After a period of time, learners' listening skill was improved, and the learners' high satisfaction with games was observed. For English reading skill, Huy (2016) reported that games could improve non-English major learners' reading skill after using games in a TOEIC class. Moreover, it was found that the learners had more participation in their learning.

In regard to English communication skill, Chantarangkul \& Campos (2018) concluded that games helped boost 
up their learners' communication skill because from the observation, 10 learners in an English for edutainment class improved their communication skill obviously after a 3-month game-based learning. Additionally, the learners had good attitudes toward using games in the classroom. Similarly, Tanasavate (2018) used games to arouse her learners' English communication skill. The participants were 15 undergraduate students. The comparison between the pretest mean score and the posttest one showed a difference at the statistical significance level of 0.05 which could be concluded that the learners' English communication skill was developed after learning with games.

Games were also used to improve EFL learners' vocabulary knowledge as can be seen in the study of Khumrod et al. (2016) which compared the learners' vocabulary size before and after learning with games. After a two-week experiment, the learners' vocabulary size was bigger in comparison to that before game-incorporated learning. Likewise, Thongkul \& Sermsook (2017) used games to develop EFL learners' recognition of English vocabulary. The participants were 30 learners in Grade 6. It was found from the findings that the learners remembered vocabulary better after learning with games for one month. They further mentioned that games were fun and interesting.

A contribution of games to the improvement of English writing skill can be viewed from the study of Indariati (2012). This study was a classroom action research where games were employed to develop high school learners' English writing ability. After learning with games, the learners' better English writing performance was observed in that they made less grammatical errors. Furthermore, the learners had good attitudes toward learning English writing through games. In the same way, Limantoro (2018) would like to improve his learners' English writing skill; therefore, word-card games were designed and used with 21 freshmen at one university in Indonesia. After a period of time, it can be concluded that the learners' writing skill significantly improved, especially in terms of vocabulary and grammar. Furthermore, Limantoro (2018) reported that those learners were satisfied with using word-card games in writing classes.

To sum up, from the previous studies, it can be concluded that games are effective for learners' English use development. In addition, learners have good atitudes toward learning English with games. However, it can be seen that there are not many experimental studies on using games to promote learners' English writing ability, especially those that focus on the ability to write in English of learners in a higher education. Consequently, a one group pretest-posttest experimental design was used in the present study to prove whether games could improve the English writing skill of learners studying in this level of education. If games are useful, it is hoped that the results from this study may shed light on the possibilities and the effectiveness of using games in English writing classes.

\section{Method}

\subsection{Research Questions}

This present study was carried out with two research questions.

1) Do error self-correcting games promote Thai EFL learners' ability to self-correct errors in written English sentences?

2) What are the learners' attitudes toward the error self-correcting games used in the writing classes?

\subsection{Research Objectives}

In parallel with the two research questions, the following two research objectives were proposed.

1) To compare Thai EFL learners' ability to self-correct errors in written English sentences before and after learning with games

2) To study the learners' attitudes toward the error self-correcting games used in the writing classes

\subsection{Participants}

Through a purposive sampling method, 26 second year English major students in Rajamangala University of Technology Srivijaya were the participants of the present study. They were four males and 22 females whose age ranged from 20 to 23 years old. Each participant has learned English as a foreign language for at least nine years.

\subsection{Instruments}

For data collection, four types of the instruments were employed.

\section{1) A 30-item Error Detection Test}

An error detection test contained 30 items of English sentences having errors. There were ten types of errors 
which were subject-verb disagreement, wrong tenses (past simple/future simple), wrong word orders, capitalization, articles, punctuations, prepositions, fragment, verb forms and literal translation from Thai to English, three items for each type. These ten error types were collected based on the errors frequently found in the participants' English sentence writing assignments. Prior to the pretest administration, the 30-item error detection test was checked by three experienced English writing teachers. The Index of Item Objective Congruence (IOC) was used to evaluate the validity of each item in the test. The IOC value was equal to 0.93 which meant that the test was highly valid. After that, the test was revised according to the three teachers' advice before being used for the actual test.

\section{2) Error Self-Correcting Games}

There were five games, each of which had ten items of incorrect English sentences. The errors in each sentence corresponded with the errors the participants encountered in the error detection test. The sentences in each game were also checked by the three experienced English writing teachers. They then were revised. Samples of English sentences containing errors are illustrated in Table 1.

Table 1. Error Types and Their Sample Sentences

\begin{tabular}{|c|c|}
\hline Error Type & Sample Sentences \\
\hline 1. Subject-verb disagreement & She have a big house. \\
\hline \multirow[t]{2}{*}{ 2. Tenses (past simple/future simple) } & My parents go to Bangkok tomorrow. \\
\hline & Yesterday some children play football. \\
\hline 3. Wrong word orders & My father likes steak fish. \\
\hline \multirow[t]{2}{*}{ 4. Capitalization } & I usually get a rose on valentine's day. \\
\hline & Students go to school on monday. \\
\hline \multirow[t]{2}{*}{ 5. Articles } & He is good guy. \\
\hline & We are eating a breakfast. \\
\hline \multirow[t]{2}{*}{ 6. Punctuations } & I eat oranges apples and grapes. \\
\hline & Next turn on the light. \\
\hline \multirow[t]{2}{*}{ 7. Prepositions } & We like to listen the radio. \\
\hline & A plane flies on the sky. \\
\hline \multirow[t]{2}{*}{ 8. Fragment } & We lazy to do homework. \\
\hline & Tom is rich. Has 10 million baht. \\
\hline \multirow[t]{2}{*}{ 9. Verb forms } & We shouldn't to walk at night. \\
\hline & I am buy some flowers. \\
\hline \multirow[t]{2}{*}{ 10. Literal Translation from Thai to English } & She name Somporn. \\
\hline & People like go a market. \\
\hline
\end{tabular}

\section{3) Non-participant Observation}

The incident where the participants were playing the games was observed and recorded by the researchers. The main topics for the observation included the class atmosphere, the participants' anxiety, their motivation and self-confidence, the participants' interaction and their ability to self-correct errors. The information from this part was further interpreted and analyzed by means of content analysis.

4) Informal Interview

Either in groups or individually, the participants were interviewed by the researchers to obtain their attitudes toward the error self-correcting games. The questions in the interview session were:

1. How do you think about the error self-correcting games used in classes?

2. Do you think that these games help you detect and correct the errors in each sentence? 


\subsection{Data Collection}

Three stages of data collection were performed in a 7-week experiment.

Stage 1: Pretest

In the first week, 26 participants took the 30 -item error detection test.

Stage 2: Game Playing

Every week for five weeks, the participants played the error self-correcting games. In the first two weeks, the error self-correcting games containing incorrect English sentences with labeled errors were presented to the participants. In the other three games for the remaining three weeks, wrong sentences without any signals of errors were shown to the participants. Before the game session, the participants were divided into two groups which had 13 members. The two teams had to compete to correct English sentences shown to them. At a time, one wrong sentence was presented, and one member from each team corrected that sentence by writing a correct one on the whiteboard. In one game, the member of the team could not be repetitive. The team that could correct a sentence in a faster time got one score. The team that could gain more total score than the other team was a winner.

\section{Stage 3: Posttest and Informal Interview}

In the last week of the experiment, all of the participants took the 30-item error detection test which was the same as the one used for the pretest. After that, every participant was interviewed by the researchers either in groups or individually. Their opinions were recorded for further interpretation.

\subsection{Data Analysis}

Two types of statistics were used to analyze the obtained data. First, descriptive statistics which were means, standard deviations and paired samples t-test were employed to analyze mean scores from the pretest and the posttest. Next, through content analysis, the data from the non-participant observation and the informal interview were grouped, interpreted and qualitatively analyzed.

\section{Results and Discussion}

The results and discussion comprise two parts corresponding with the two research questions and research objectives proposed earlier.

\subsection{Thai EFL Learners' Ability to Self-Correct Errors in Written English Sentences before and after Learning with Games}

The mean scores of the pretest and of the posttest were compared through the paired samples t-test to determine whether there was any significant difference in the participants' ability to self-correct errors before and after learning with games. Table 2 demonstrates the pretest and posttest mean scores.

Table 2. The Participants' Pretest and Posttest Mean Scores

\begin{tabular}{ccccccc}
\hline Test & N & Mean & S.D. & t & df & Sig. (2-tailed) \\
\hline Pretest & 26 & 13.58 & 6.45 & 7.48 & 25 & $0.00^{* *}$ \\
Posttest & 26 & 18.65 & 6.05 & & &
\end{tabular}

$* * \mathrm{p}<0.01$

Based on the figures in Table 2, it can be assumed that the games helped enhance the participants' error self-correction ability. Out of the full score of 30 , the participants' posttest mean score $(\bar{x}=18.65$, S.D. $=6.05)$ was higher than the pretest one $(\bar{x}=13.58$, S.D. $=6.45)$ at the 0.01 statistical significance level. This finding lends support to the findings from previous studies which used games to encourage learners' English ability and reported the effectiveness of games on developing learners' English use in various skills (Andyani, 2012; Chantarangkul \& Campos, 2018; Huy, 2016; Khumrod et al., 2016; Tanasavate, 2018). More importantly, the findings arisen from the present study add more evidence in that games can be helpful in English writing classes which are in consistent with the findings from past studies, for instance, Indariati (2012) who found that games improved EFL learners' use of English vocabulary and grammar in their writing and Limantoro (2018) who reported the usefulness of games on the improvement of his participants' English writing skill. 


\subsection{The Learners'Attitudes toward the Error Self-Correcting Games used in the Writing Classes}

The information in this part was divided into two parts according to the two instruments used: non-participant observation and informal interview.

Non-participant Observation Session

The incident during a five-week game-incorporated learning was observed and recorded by the researchers. Before the games, the participants felt excited. After they were divided into groups, they started to make the sequence of the players in each round. During the game, the participants who were not the player in each round shouted to cheer up their friend. Although their friend did not win the game, they were not angry at their friend. Instead, they said something to console that friend. Learners' and teachers' laughter and smile were observed during the game session. After the game ended, some participants in the winning team comforted the friends in the losing team. And it was found that the participants were able to correct errors in English sentences even though there were no signals of errors.

Based on the information from this session, three points can be raised. The first one is a positive interaction and harmony among the participants. They learned to work as a team. Another one is an enjoyable atmosphere in the writing classroom where the participants feel relaxed, have fun, and more importantly are motivated to learn. The last one is the participants' ability to self-detect and self-correct errors in English sentences.

\section{Informal Interview Session}

The participants' comments were grouped and qualitatively analyzed. The information from this session can be categorized into four points.

1) Games are entertaining. They can make the lesson more interesting and lessen learners' anxiety. They turn a boring English classroom into a joyful one.

2) Games make the participants more self-confident to use English. Games can encourage the participants to learn and to have more participation in their learning.

3) Games can help reinforce the participants' knowledge as learners try to recall what they have learned. Through this way of learning, learners may have better memory of knowledge for their further use.

4) Games make the participants find the importance of writing correct English sentences for their effective communication. Furthermore, they find the importance of teacher corrective feedback either direct or indirect type.

An analysis of the information obtained from the non-participant observation and the informal interview reveals that the participants have positive attitudes toward playing games in their writing classroom. The games motivated them to learn and to use the language. Moreover, they had fun and excitement in class. This positiveness may be the reason why the participants did better in their posttest as it is said that language learners whose learning attitudes are positive tend to be successful in their language learning (Bilash, 2009; Syukur, 2016).

With respect to a class atmosphere, it can be said that the class was relaxing with learners' and teacher's laughter and smile. No boredom existed while games were being played. These findings support the ones from the previous studies (Andyani, 2012; Bush, 2015; Cam \& Thu Tran, 2017; Chantarangkul \& Campos, 2018; Sermsook, 2018; Tanasavate, 2018), all of which reported that learners were satisfied with using games in classes, and games motivated them to learn in an enjoyable class atmosphere. Additionally, one interesting finding arisen from the present study is that games can help the learners become aware of and find the importance of teacher corrective feedback. This can be assumed that a language teacher plays a vital role as a supporter or a facilitator in learners' successful language learning. Furthermore, learners found how essential correct English sentences are by themselves which may result in their better memory of knowledge since they would like to keep the knowledge for their further use. Therefore, it is recommended that game-based learning be considered an essential part of language learning in order to help both learners and teachers accomplish the expected learning goals.

Another interesting point that can be obtained from the findings is that games can boost up the learners' teamwork and collaboration. These findings lend support to the findings from the past studies (e.g. Huy, 2016; Sermsook, 2018) which state that learners' more participation and good interaction among them were observed when games were played.

Based on the findings from the present study, it can be concluded that games are helpful for language learning. They help both learners and teachers achieve the learning targets. Games, in addition, guide learners to work 
together with love and harmony.

\section{Pedagogical Implication}

The present study provides some pedagogical implications that may be useful for language teaching. First, games are beneficial to English writing learning. In particular, they encourage learners to self-detect and self-correct errors in English sentences. They are also useful for teaching other skills of English as evidenced by the findings from past studies. Furthermore, games can create an atmosphere contributing to language learning by changing a stressful classroom to an entertaining one. Another benefit of games on language learning is that games make learners have good attitudes toward English learning and strengthen their self-confidence which leads to their more participation in learning. Next, teacher corrective feedback is still a necessary tool for language learning since it can help learners stay in the right way of their learning. Lastly, games can help learners interact with one another. This results in their learning to work in a team which is one of essential life and work skills (Barrett, 2017). They find the importance of themselves and their friends.

\section{Conclusion}

The objectives of the present study were to use games to promote Thai EFL learners' ability to self-correct errors in written English sentences and to study the learners' attitudes toward using games in the writing class. From the results, it can be seen that games, in no doubt, are effective for language learning. Games motivate learners to learn the language and encourage them to have more participation in their learning. Moreover, games make a classroom pleasant for learners' learning. Therefore, there should be no hesitation to include games in any language classes or in curriculum. Most importantly, teachers and other concerned people need to make sure that games are designed based on the relating factors as suggested by some scholars. The findings from this study, to a certain degree, add more evidence and provide some useful points about the effectiveness of using games in classes, particularly using games to enhance undergraduate students in a writing class. People in related fields may make use of games for their teaching management. However, as the present study was conducted with only 26 participants and within seven weeks due to the time limit, the generalization of the results with other groups of learners should be cautiously considered.

\section{References}

Andyani, H. (2012). Using fun activities to improve listening skill. Journal on English as Foreign Language, 2(2), 29-36. https://doi.org/10.23971/jefl.v2i2.54

Ashok, M. L., Revathi, P. S. \& Saminathan, P. B. (2013). Effectiveness of language games in learning English grammar. Shanlax International Journal of Education, 1(3), 16-23.

Barrett, D. (2017). Teamwork is a valuable work and life skill. Retrieved from https://www.canr.msu.edu/news/teamwork_is_a_valuable_work_and_life_skill

Bilash, O. (2009). Positive attitude. Retrieved from www.educ.ualberta.ca/staff/olenka.bilash/Best $\% 20 \mathrm{of} \% 20$ Bilash/positiveattitude.html

Bush, J. C. (2015). The impact of classroom games on the acquisition of second language grammar. Language in Focus Journal, 1(2), 17-29. https://doi.org/10.1515/lifijsal-2015-007

Cam, L. \& Thu Tran, T. M. (2017). An evaluation of using games in teaching English grammar for first year English-majored students at Dong Nai Technology University. International Journal of Learning, Teaching and Educational Research, 16(7), 55-71.

Case, A. (2019). The most effective error correction games. Retrieved from https://www.usingenglish.com/articles/most-effective-error-correction-games.html

Chantarangkul, V. \& Campos, E. S. (2018). Using communicative games in English for edutainment. Proceedings of the $49^{\text {th }}$ ISAGA Conference on Active Learning and Neo-Simulation \& Gaming: Sharing Wisdom (pp. 182-190). Nakhon Pathom, Thailand: Mahidol University.

Chen, I. (2015). Using games to promote communicative skills in language learning. The Internet TESL Journal, $11(2), 1-3$.

Chirandon, A., Laohawiriyanon, C. \& Rakthong, A. (2010). The effects of teaching English through games. Proceedings of the $2^{\text {nd }}$ International Conference on Humanities and Social Sciences (pp. 54-60). Songkhla, Thailand: Prince of Songkla University.

Constantinescu, R. S. (2012). Learning by playing: Using computer games in teaching English grammar to high school students. E-learning \& Software for Education, 2, 110-115. 
Crystal, D. (1997). English as a global language. Cambridge: Cambridge University Press.

Huy, N. T. (2016). The positive impacts of using games in teaching TOEIC reading skill for non-major English students at Dong Thap University. Asian Journal of Educational Research, 4(1), 42-48.

Ibrahim, A. (2017). Advantages of using language games in teaching English as a foreign language in Sudan basic schools. American Scientific Reseach Journal for Engineering, Technology, and Sciences, 37(1), $140-150$.

Indariati, D. (2012). Improving students' writing competence using game (bouncing stories) (Unpublished master's thesis). Sebelas Maret University, Indonesia.

Jenkins, J. (2003). World Englishes: A resource book for students. London: Rontledge.

Khunmohammad, H., Gorjian, B. \& Eskandari, Z. (2014). Using games to affect learners' motivation in learning English grammar. International Journal of Language Learning and Applied Linguistics World, 5(3), 324-341.

Khumrod, K., Yiamkhantithaworn, S. \& Meejiang, A (2016). The effects of using games on English vocabulary learning and retention of prathom suksa V students. Journal of Graduate Studies Valaya Alongkorn Rajabhat, 10(2), 1-10.

Kim, L. S. (2000). Creative games for the language class. Forum, 33(1), 35-36.

Klimova, B. F. (2015). Games in the teaching of English. Procedia Social and Behavioral Sciences, 191, 1157-1160. https://doi.org.10.1016/j.sbspro.2015.04.312

Koksal, O., Cekic, A. \& Beyhan, O. (2014). Views of Turkish EFL students with regard to learning grammar with games. International Journal on New Trends in Education and Their Implications, 5(1), 82-92.

Lackman, K. (2010). Error correction games for writing. Retrieved from www.kenlackman.com/files/WritingErrorsBook10A4.pdf

Limantoro, S. W. (2018). Developing word-card games to improve English writing. International Journal of Teaching, Education and Learning, 2(3), 38-54. https://doi.org.10.20319/pijtel.2018.23.3854

Martin, J. (2016). Research shows how gaming can support language learning. Retrieved from https://www.english.comblg./

Sermsook, K. (2018). Using a game to promote students' self-correction of grammatical errors. Proceedings of the $49^{\text {th }}$ ISAGA Conference on Active Learning and Neo-Simulation \& Gaming: Sharing Wisdom (pp. 704-712). Nakhon Pathom, Thailand: Mahidol University.

Syukur, A. (2016). Encouraging students to have positive attitudes toward learning English. Ethical Lingua: Journal of Language Teaching and Literature, 3(2), 122-130. https://doi.org/10.30605/25409190.v3.02.122-130

Tanasavate, K. (2018). Using games in communicative language teaching classroom to improve students' English communication skills: A case study of Rajamangala University of Technology Srivijaya, Trang campus, Thailand. Proceedings of the $49^{\text {th }}$ ISAGA Conference on Active Learning and Neo-Simulation \& Gaming: Sharing Wisdom (pp. 173-181). Nakhon Pathom, Thailand: Mahidol University.

Thongkul, K. \& Sermsook, K. (2017, February). Using vocabulary games to develop English vocabulary recognition of prathomsuksa 6 students at Chumchon Wat Samrong school. Paper presented at the $2^{\text {nd }}$ National Conference on Sciences and Social Sciences, Nakhon Si Thammarat, Thailand.

Wulandari, E. (2016). Promoting fun learning in writing through games. Journal of English Education, Literature, and Culture, 1(2), 143-157. http://dx.doi.org/10.30659/e.1.2.143-157

\section{Copyrights}

Copyright for this article is retained by the author(s), with first publication rights granted to the journal.

This is an open-access article distributed under the terms and conditions of the Creative Commons Attribution license (http://creativecommons.org/licenses/by/4.0/). 